\title{
Sustainable Energy Development in Canada's Mackenzie Delta-Beaufort Sea Coastal Region
}

\author{
KELTIE VOUTIER, ${ }^{1}$ BHARAT DIXIT, ${ }^{2}$ PETER MILLMAN,${ }^{3}$ JOHN REID ${ }^{4}$ and ADAM SPARKES ${ }^{5}$
}

\author{
(Received 26 June 2007; accepted in revised form 10 December 2007)
}

\begin{abstract}
The oil and gas sector is returning to the Mackenzie Delta-Beaufort Sea region of Canada's western Arctic after a decade-long absence. If brought into production, the hydrocarbon resources in this region could generate significant long-term economic and social benefits for Canadians in general and for Northerners in particular. An evolving regulatory environment, the impacts of climate change, and a lack of infrastructure, however, are creating unanticipated challenges for industry and regulators alike. In addition, aboriginal and other northern stakeholders are largely supportive of oil and gas activity, but only provided they have assurances that communities will benefit and that any negative impacts will be mitigated. Regulators, industry, and stakeholders are, therefore, working closely together to ensure that resource management balances economic, environmental, and social considerations.
\end{abstract}

Key words: sustainable energy development, Beaufort Sea, Mackenzie Gas Project, Beaufort Sea Strategic Regional Plan of Action, Devon Canada Corporation, Inuvialuit

RÉSUMÉ. Après dix ans d'absence, le secteur de l'exploration du pétrole et du gaz refait surface dans la région du delta du Mackenzie et de la mer de Beaufort située dans la partie ouest de l'Arctique canadien. Si les ressources en hydrocarbures de cette région entraient en production, cela pourrait se traduire par d'importantes retombées socio-économiques à long terme pour les Canadiens en général et pour les gens du Nord en particulier. Cependant, le milieu réglementaire en pleine évolution, les incidences du changement climatique et le manque d'infrastructure posent des défis imprévus, tant à l'industrie qu'aux organismes de réglementation. De plus, les parties prenantes autochtones de même que les autres parties prenantes du Nord se prononcent fortement en faveur des activités pétrolières et gazières, mais seulement s'ils ont la certitude que les collectivités en bénéficieront et que les incidences négatives seront limitées. Par conséquent, les organismes de réglementation, l'industrie et les parties prenantes travaillent en étroite collaboration pour s'assurer que la gestion des ressources donne lieu à un équilibre entre les considérations économiques, environnementales et sociales.

Mots clés : développement durable de l'énergie, mer de Beaufort, projet gazier Mackenzie, plan d'action stratégique et régional de la mer de Beaufort, Devon Canada Corporation, Inuvialuit

Traduit pour la revue Arctic par Nicole Giguère.

\section{INTRODUCTION}

This paper synthesizes the panel discussion entitled "Sustainable Energy Development in the Arctic Offshore" held at the Coastal Zone Canada Conference 2006 in Tuktoyaktuk, Northwest Territories. After a brief overview of the hydrocarbon resources of the Mackenzie Delta-Beaufort Sea region of Canada's western Arctic, it identifies the key factors motivating industry's return to the region and highlights some of the regulatory, environmental, and infrastructure challenges that must be met to bring these resources into production. Oil and gas activity is influencing the need for coastal zone planning in the western
Arctic. The Beaufort Sea Strategic Regional Plan of Action, a "made-in-the-North" approach to multi-stakeholder involvement in resource-management decision making, is grounded on the principles of sustainable development. A postscript provides an update to December 2007 on major developments since the Coastal Zone Canada Conference in August 2006.

\section{HYDROCARBON POTENTIAL}

It is estimated, on the basis of exploration activity in the 1970s and 1980s, that the three territories and the adjacent

\footnotetext{
${ }^{1}$ Frontier Lands Management Division, Energy Sector, Natural Resources Canada, 17th Floor, 580 Booth Street, Ottawa, Ontario K1A 0E4, Canada; kvoutier@nrcan.gc.ca

${ }^{2}$ Exploration and Production, National Energy Board, 444-7th Avenue SW, Calgary, Alberta T2B 0X8, Canada; bdixit@ neb-one.gc.ca

${ }^{3}$ Devon Canada Corporation, 2000, 400-3rd Avenue SW, Calgary, Alberta T2P 4H2, Canada; peter.millman@devoncanada.com

${ }^{4}$ Inuvialuit Joint Secretariat, 107 Mackenzie Road,P.O. Box 2120, Inuvik, Northwest Territories X0E0T0, Canada; bsstrpa@ joint.sec.nt.ca

${ }^{5}$ Canadian Association of Petroleum Producers, 2100, 350-7th Avenue SW, Calgary, Alberta T2P 3N9, Canada; adam.sparkes@ capp.ca

(C) The Arctic Institute of North America
} 


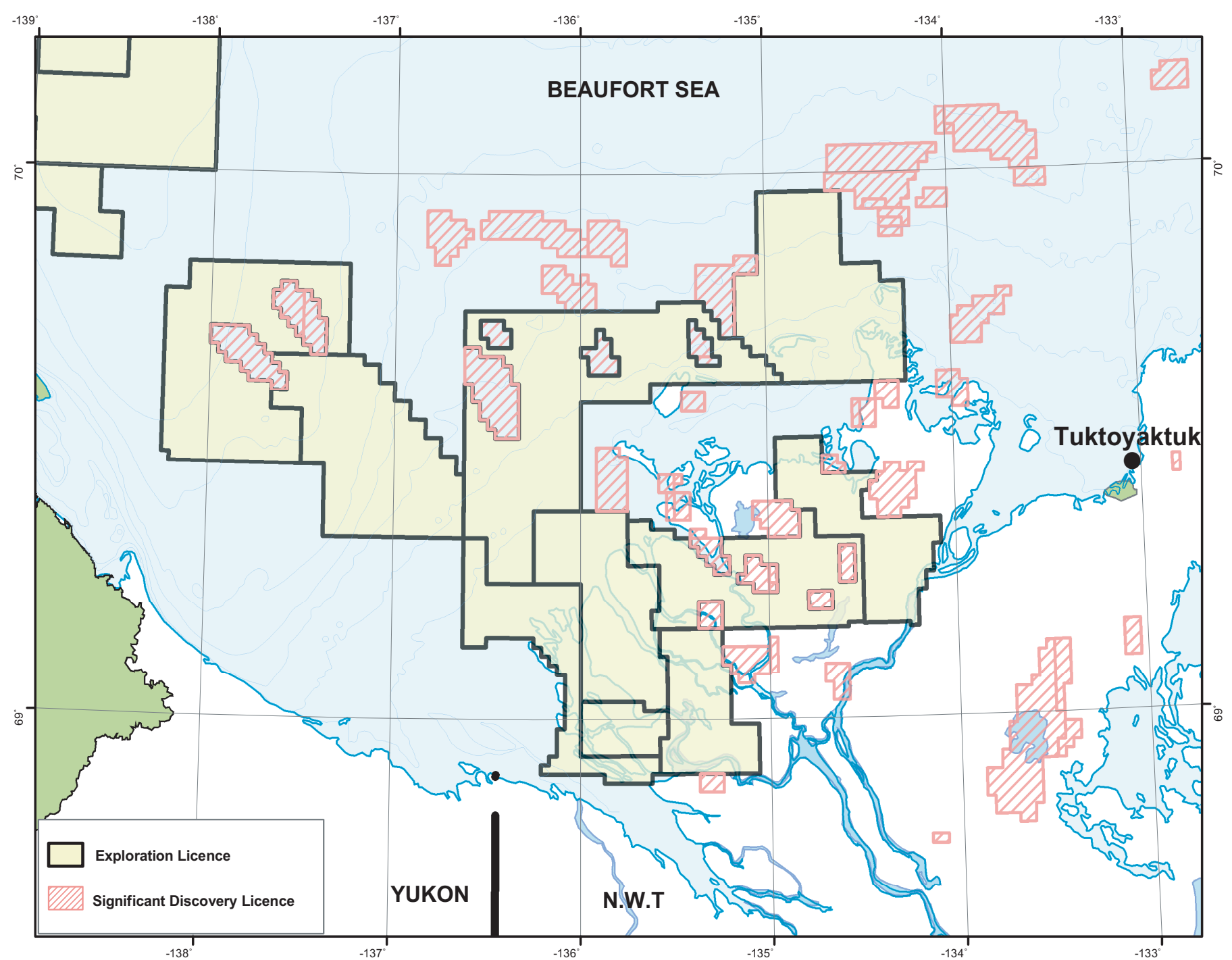

FIG. 1. Historical and current oil and gas activity in the Mackenzie Delta-Beaufort Sea region. (Reproduced with permission from the Northern Oil and Gas Branch, Indian and Northern Affairs Canada.)

Arctic offshore hold approximately $30 \%$ of Canada's remaining potential in conventional oil and natural gas, or about 8.7 billion barrels of oil and 163 trillion cubic feet of natural gas (Drummond, 2002). The area of primary interest for industry at present is the Mackenzie Delta-Beaufort Sea sedimentary basin in the western Arctic. It is currently estimated to contain 5.8 billion barrels of oil and 58 trillion cubic feet of natural gas (Drummond, 2002). To put these resources in perspective, one trillion cubic feet of natural gas is sufficient to heat all the houses in Canada for one year.

Figure 1 illustrates past and current exploration in the Mackenzie Delta-Beaufort Sea sedimentary basin. It shows that many of the pink areas, which indicate "significant discoveries" determined from past exploration activity to have the potential for production, contain an onshore as well as an offshore component. Similarly, many of the new exploration licences (the yellow areas) also straddle the onshore/offshore boundary. From the perspective of hydrocarbon engineering and coastal resource management, therefore, the delineation of "onshore" and "offshore" becomes blurred-especially because much of the shallow Beaufort Sea is frozen solid in winter, making it indistinguishable from the nearby shore, and because directional drilling from onshore locations can penetrate targets at depth several kilometres offshore. Consequently, terrestrial and marine oil and gas activities in this region require a higher degree of coordination than anywhere else in Canada, if not the world.

\section{EXPLORATION ACTIVITY}

Most of the significant discoveries shown in Figure 1 were made during exploration activity in the 1970s and 1980s (INAC, 2007a). Fuel price shocks during this era, in combination with generous federal financial and tax incentives, made exploration in the Mackenzie Delta-Beaufort Sea region very attractive to industry as an investment opportunity (Clark et al., 1997; Voutier et al., 2002). By 
the late 1980s, however, fuel prices had returned to preprice shock levels, and government incentives had been terminated with the demise of the National Energy Program (Clark et al., 1997; Voutier et al., 2002). The region was no longer competitive with other investment opportunities in Canada or worldwide. As a consequence, industry investment moved elsewhere, and most of the infrastructure-such as icebreakers, supply ships, and drilling platforms-was either decommissioned or redeployed to other exploration frontiers (Clark et al., 1997).

There was virtually no oil and gas activity in the Mackenzie Delta-Beaufort Sea region throughout most of the 1990s. By the turn of the millennium, however, several developments-rising energy prices, concerns over continental energy security, and a focus on clean energy - had coalesced to encourage a consortium of companies, now known as the Mackenzie Gas Producers, to contemplate a return to the Mackenzie Delta. Their attention was focused on three existing significant discoveries, the so-called "anchor fields" of Niglintgak, Taglu, and Parsons Lake, collectively containing an estimated 5.7 trillion cubic feet of natural gas (INAC, 2007b). Bringing this natural gas to southern markets will involve field development, as well as the construction of a $1200 \mathrm{~km}$ underground natural gas pipeline to tie into existing pipeline infrastructure in northern Alberta (Fig. 2). It will also require construction of an $800 \mathrm{~km}$ underground pipeline for liquids to transport oil condensate in the natural gas to the Norman Wells oil pipeline in the mid-Mackenzie Valley. The 2006 estimated cost of the project, which is currently undergoing environmental review, was $\$ 7$ billion (Imperial Oil Limited et al., 2007).

The prospect of pipeline infrastructure, coupled with rising energy costs, has encouraged other companies to reexamine Mackenzie Delta-Beaufort Sea hydrocarbon potential. Since 1999, companies have committed over $\$ 1.5$ billion in exploration activity to find new hydrocarbon resources in the region (INAC, 2007a). This investment has had a significant impact on the local economy; however, given the high costs of northern operations, it has enabled only a handful of companies to establish a presence in the North. Moreover, most of industry's attention has been focused on the Mackenzie Delta, where operating costs are relatively lower than in the Beaufort Sea, and only two companies (Devon Canada Corporation and Shell Canada Limited) have committed funding for exploration activity that would take place entirely offshore (INAC, 2007a).

Construction of pipeline infrastructure is pivotal to the ongoing development of hydrocarbon resources in the Mackenzie Delta-Beaufort Sea basin beyond the anchor fields. Should the Mackenzie Gas Project proceed, for example, it would provide the capacity to transport 1.2 billion cubic feet of natural gas per day, of which 800 million cubic feet per day would come from the anchor fields (Imperial Oil et al., 2007). The surplus capacity, some 400 million cubic feet per day, would need to be filled from other existing or incremental discoveries. Ultimately, the pipeline infrastructure from the Mackenzie Gas Project could expand to tap into offshore resources in the Beaufort Sea.

\section{REGULATORY, ENVIRONMENTAL AND INFRASTRUCTURE CHALLENGES}

\section{Regulatory Challenges}

Many northern operating challenges must be addressed before a sustained period of hydrocarbon activity in the western Arctic becomes a reality. The regulatory environment in the North, for example, has become more challenging since the last round of exploration activity, largely in response to increased concerns over environmental and social impacts. The introduction of new legislation such as the Canadian Environmental Assessment Act and the Species at Risk Act, together with growing expectations for consultation with community organizations, have the potential to increase timelines associated with project approvals. Although all stakeholders-aboriginal groups, northern communities, industry, and governments-agree that decisions affecting northern energy development need to balance environmental, economic, and social objectives, this desired balance has not necessarily made current regulatory processes easier to navigate.

For example, consider Devon Canada Corporation's environmental assessment for its Beaufort Sea Exploration Program. The first well (Paktoa C-60) of this drilling program was completed during the 2005-06 winter season. As the first offshore exploration well in the Canadian Beaufort Sea in over 16 years (INAC, 2007a), it was required to undergo a comprehensive study under the Canadian Environmental Assessment Act, as well as an environmental screening under the Inuvialuit Final Agreement. Regulators did work with the proponent to minimize the regulatory burden by coordinating information requirements and by agreeing upon a schedule and process for the review. Nonetheless, it took two years to complete the required environmental review, at a cost of several million dollars to the company.

For its part, industry understands the need for rigorous assessment processes. It is concerned, however, that an increasingly cumbersome regulatory regime will undermine the attractiveness of the Mackenzie Delta-Beaufort Sea region as an investment opportunity. At the same time, aboriginal groups and northern communities largely support energy development, provided that the assessment processes assure them that they will benefit and that any negative impacts will be mitigated. Given the legislative changes and increased pressures for community consultations, a two-year assessment process is perhaps understandable for this millennium's first exploration well in the Beaufort Sea. One would, nonetheless, expect processes to become more efficient with experience, an 


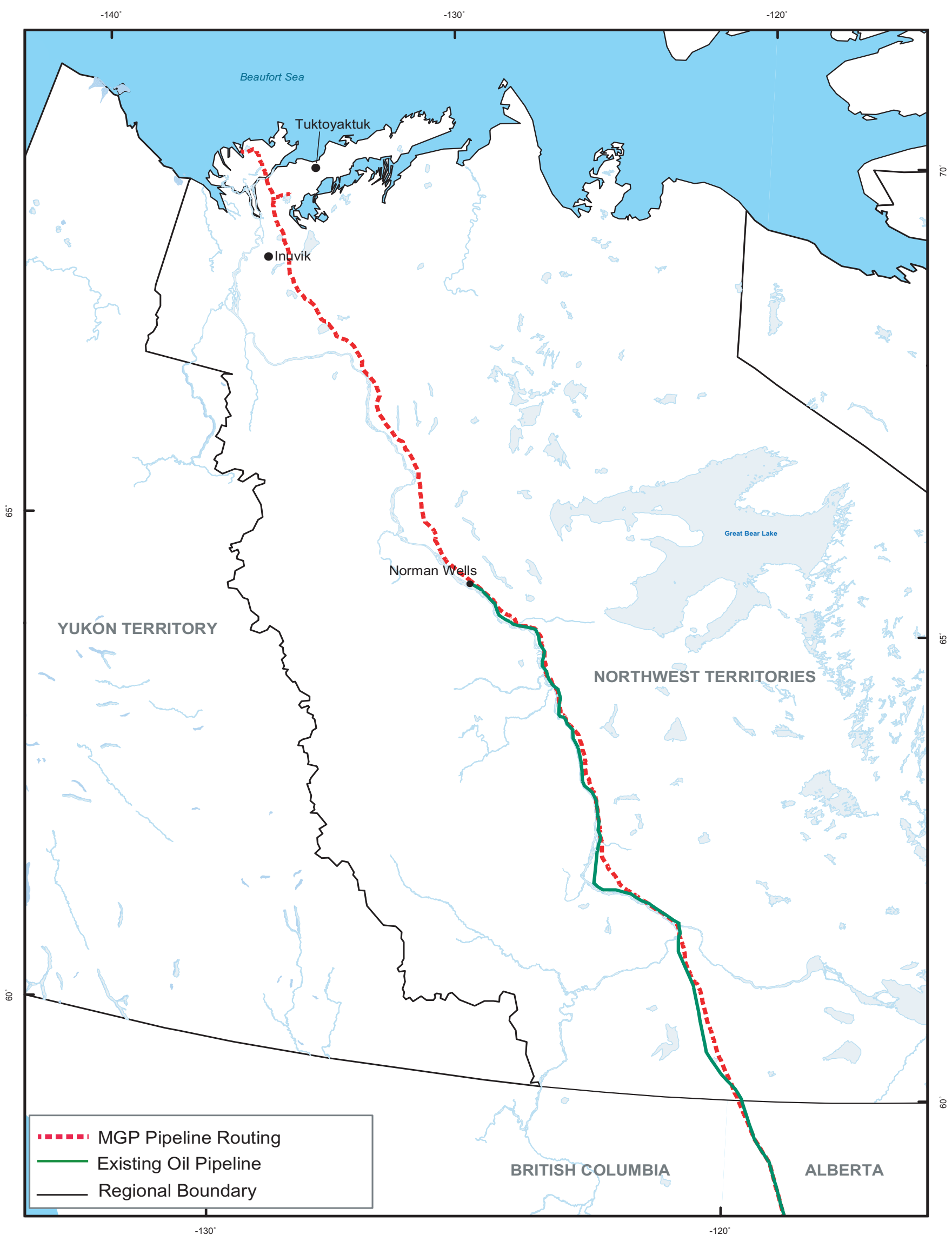

FIG. 2. Anchor fields and pipeline route for the Mackenzie Gas Project. (Reproduced with permission from the Northern Oil and Gas Branch, Indian and Northern Affairs Canada.) 
enhanced awareness of stakeholder concerns, an improved understanding of exploration drilling technology, an everincreasing scientific knowledge base, and greater consideration of aboriginal traditional knowledge.

\section{Environmental Challenges}

The harsh northern climate severely limits operations in both the summer and the winter months, making the North a high-cost exploration opportunity compared to other petroleum basins in Canada or worldwide (Clark et al., 1997). Climate change, which is having a greater impact on the North than elsewhere, could potentially affect future exploration projects. Melting permafrost, for example, could affect sumps from past activity. Sumps are essentially excavations near an onshore exploration site that are used for the disposal of drilling mud, rock cuttings, and other non-recyclable by-products of the drilling program. Regulators are working with industry and northern stakeholders to understand climate-change impacts on sumps and to develop design features that will help ensure their stability. In addition, the National Energy Board, along with other regulators and stakeholders, is currently examining whether down-hole injection (re-introducing the by-product material into the underground reservoirs) could be an alternative disposal technique that is environmentally, economically, and technically acceptable.

Devon Canada Corporation's experience with the Paktoa C-60 exploration well also provides instructive insights into the environmental challenges of northern operations. During the environmental assessment process, the company undertook studies to evaluate the variability of the environment and its potential impact on exploration operations. In particular, it listened to comments from local communities that the zone of landfast ice had changed substantially since the last round of activity. Landfast ice is sea ice containing segments that are anchored solidly to the seabed; it provides a stable platform from which drilling and support operations can safely be conducted (Clark et al., 1997).

In response to this information from the communities, Devon completed a hindcast ice study reviewing the formation and breakup of landfast ice at each of Devon's potential drilling locations over a 10-year period (19912002). The results of the analysis validated community observations on changes to landfast ice patterns but also indicated that ice conditions would not prevent a drilling program from being completed at any of Devon's offshore locations. Although the study was not adequate to determine whether the observed changes to ice patterns were the result of climate change or would continue over the long term, it nonetheless reinforced the need to integrate information on the physical environment into project planning to ensure that appropriate safety factors are built into operations.

Unlike regulatory challenges, which will become more manageable with experience and practice, the harsh Arctic environment and the impacts of climate change will continue to be factors that must be considered in project design for future northern operations. These factors will not only affect facilities and operational flexibility but could also pose health and safety challenges. For example, increased days of inclement weather could affect transportation, particularly aviation, which is heavily used in northern exploration to move personnel, supplies, and equipment. Addressing these challenges will require the ongoing application of technical innovation as well as regulatory flexibility.

\section{Infrastructure Challenges}

We noted earlier that much of the infrastructure used during the last round of exploration activity in the Mackenzie Delta-Beaufort Sea was moved from the region in the late 1980s. This removal has posed serious constraints as industry seeks to return to the region. Not only is northern exploration now funded entirely by private companies, but northern programs must also compete for funds at the company level against other Canadian and international exploration opportunities. A return to exploration is particularly daunting in the Beaufort Sea because much of the infrastructure from the previous exploration era was purpose-built, highly specialized, and very expensive (Clark et al., 1997).

Devon's experience can once again be used to illustrate the significance of these northern operating challenges. During the planning for its Beaufort Sea Exploration Program, the company reviewed all winter and summer drilling systems that had been used previously in the Canadian Beaufort Sea. Of all these systems, only one fabricated platform was available and in useable condition. All the others had been mothballed or demobilized from the Canadian Beaufort or were not conducive to a winter drilling program in water depths specific to Devon's offshore acreage.

The sole exception (Fig. 3) was the Steel Drilling Caisson (SDC), which Devon was able to obtain for a winter drilling program after it had completed an offshore contract in Alaska. The SDC is a self-contained drilling system that was built for the purpose of Canadian Beaufort Sea winter exploration in the 1980s (Clark et al., 1997). The upper portion of the SDC, which contains the drilling platform and crew accommodations, is the converted forebody of a supertanker reinforced with $1 \mathrm{~m}$ thick concrete and extra steel supports. The lower portion or "MAT" is classed as a submersible barge, measuring roughly $160 \times 110 \mathrm{~m}$. Constructed of low-temperature steel, the MAT has box-type skirts $2 \mathrm{~m}$ long covering the entire base of the system. These skirts anchor the MAT to the sea floor and provide sliding resistance.

Once it was towed to location at the Paktoa C-60 drilling site, the SDC was ballasted until the structure achieved a stable position on the sea floor. Drilling operations commenced in early December 2005 and were 


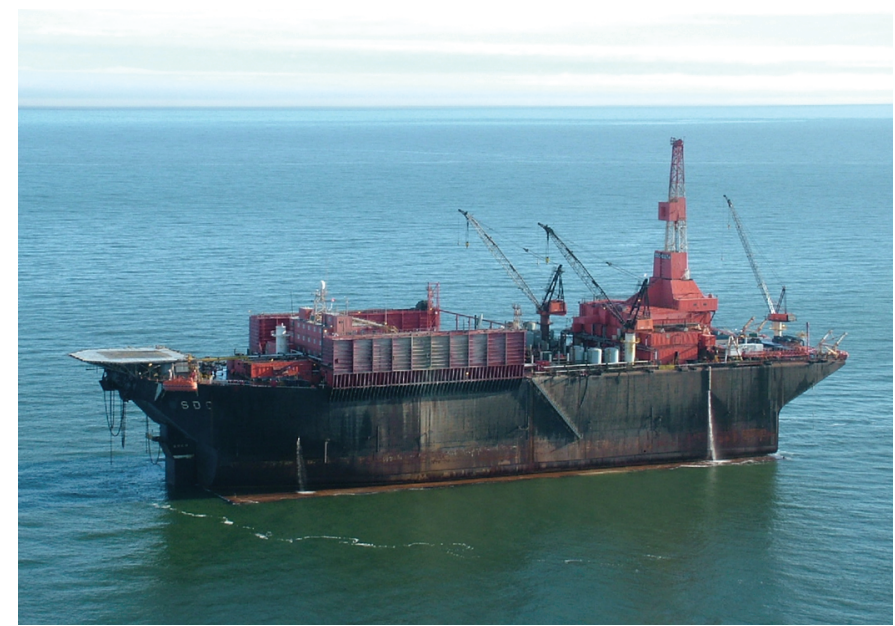

FIG. 3. The Steel Drilling Caisson (SDC) on location at Devon's Paktoa C-60 exploration well. (Reproduced with permission from Devon Canada Corporation.)

completed in late March 2006. The equipment and personnel involved allowed the project to meet both the operational and the geological objectives on budget. In addition, operations were conducted in a manner that was safe, environmentally responsible, and respectful of Inuvialuit concerns. Devon Canada Corporation is currently preparing an application for approval of a Significant Discovery Licence for hydrocarbons encountered as a result of the drilling program.

\section{INFLUENCING THE NEED FOR COASTAL ZONE PLANNING}

Given the number of hydrocarbon deposits in the Mackenzie Delta-Beaufort Sea region that straddle the onshore-offshore boundary, it should come as no surprise that oil and gas activity is intensifying pressures for coastal zone planning in this portion of the western Arctic. Since the late 1990s, petroleum companies have acquired large tracts of exploration property that either contain an offshore component or are located entirely offshore, and active exploration programs are underway. Furthermore, barge and freighter traffic has increased in both the Beaufort Sea and the Mackenzie River as exploration companies bring in supplies for their activities throughout the region. Air traffic is also increasing as workers move north to seek employment opportunities and generate a growing demand for perishable food items. The growing labour force, in turn, is stretching community infrastructure, which has resulted in the re-opening of oil and gas camps from the last round of activity and the construction of new hotels, houses and related facilities, notably in the communities of Inuvik and Tuktoyaktuk.

Oil and gas exploration and development are, and hold the potential to remain, the most significant engines of economic growth in this region. If managed correctly, hydrocarbon development can provide for the long-term prosperity of the coastal communities that dot the Beaufort Sea and bring significant economic benefits to the rest of Canada. There are, nonetheless, concerns that other values, including maintenance of traditional lifestyles and protection of ecologically sensitive areas, must also be safeguarded before hydrocarbon activity expands beyond current levels.

\section{BEAUFORT SEA STRATEGIC REGIONAL PLAN OF ACTION}

The issue of the long-term environmental and social sustainability of the Mackenzie Delta-Beaufort Sea region in the wake of the new wave of oil and gas activity resulting from the Mackenzie Gas Project was first brought to light by the Inuvialuit Game Council. In June 2004, the Council wrote to David Anderson, then Minister of the Environment, to express concerns that environmental assessment processes tended to focus on individual projects and might not adequately capture the cumulative environmental and social impacts of an extended period of oil and gas activity induced by pipeline construction (Pokiak, 2004). The letter requested that the "Canadian Environmental Assessment Agency undertake a strategic regional environmental assessment of the development of offshore oil and gas resources in the Beaufort Sea and the impacts of this development on the communities surrounding the Beaufort Sea" (Pokiak, 2004:1).

The succeeding Minister, Stéphane Dion, responded favourably to this request, noting that he found the "proposal for a regional strategic environmental assessment to prepare for future exploration and development [to be] both prudent and timely" (Dion, 2004:1). He indicated that any such initiative, in addition to Inuvialuit participation, would require cooperation among a number of federal and territorial organizations. He also noted that other environmental assessments, including that underway for the Mackenzie Gas Project and Devon Canada's offshore exploration program, "would need to be considered in determining the scope of any regional environmental assessment to be undertaken" (Dion, 2004:1).

A workshop was held in Inuvik the following May to launch a process for developing the Beaufort Sea Strategic Regional Plan of Action (the Strategic Regional Plan). The workshop highlighted the need to take a community-based approach in identifying regional needs and to include traditional knowledge, as well as science, in decision making. The workshop also articulated five overall objectives of the Strategic Regional Plan: (1) to protect the environment from significant adverse impacts of proposed developments; (2) to protect and promote the social, cultural, and economic well-being of Inuvialuit communities and residents; (3) to encourage responsible economic development within a sound environmental management framework; (4) to provide a "roadmap" to help clarify the environmental assessment and resource management 
regimes offshore; and (5) to enable Inuvialuit communities and residents to fully participate in developing the Strategic Regional Plan.

In some respects, development of the Strategic Regional Plan is focusing attention on the carrying capacity of the region for oil and gas activity, both in the Beaufort Sea and in the nearby outer fringes of the Mackenzie Delta. In this context, the plan will need to consider how hydrocarbon activity can be managed to protect social and cultural values, migratory species, and sensitive ecological regions, while also maintaining an attractive investment climate for industry. To their credit, the proponents of the Strategic Regional Plan have developed both an organizational structure and a work plan to complete this work.

In terms of structure, the initiative is being spearheaded by the Inuvialuit Game Council with Inuvialuit Settlement Region organizations, federal and territorial governments, and industry participating in an overarching steering committee, as well as on a number of issue-specific technical advisory committees (TACs). The TACs are responsible for the key elements of the work plan, including an assessment of (1) the biophysical, social, cultural, and economic environments; (2) climate change impacts; (3) the regulatory regime; (4) cumulative impacts; (5) industry development scenarios; and (6) best industry practices. Finalization of the Strategic Regional Plan was scheduled for 31 March 2007. This work, once it is completed, is expected to help identify priority actions for implementation. It will also form the basis for recommendations to the various stakeholder organizations on the roles they will need to play in meeting the objectives identified above.

\section{CONCLUSION}

The Mackenzie Delta-Beaufort Sea region may be on the brink of a prolonged period of oil and gas activity. Significant hydrocarbon resources are known to exist in the region; the prospect of pipeline infrastructure looms large; petroleum companies are interested in exploring for new discoveries; and stakeholders largely support oil and gas activity, provided that local communities benefit and any negative environmental and social impacts are mitigated. Although there are many regulatory, environmental, and infrastructure challenges to be overcome, stakeholders are working together to try to find effective solutions and to ensure that the carrying capacity of the region for oil and gas activity is respected. There is no guarantee that the processes and mechanisms currently in place to help guide oil and gas exploration and development in the Mackenzie Delta-Beaufort Sea region will strike an adequate balance between competing environmental, social, and economic objectives. It is absolutely certain, however, that in the absence of processes and mechanisms such as these, the sustainable development of northern energy resources for the benefit of all Canadians, and for the benefit of Northerners in particular, is simply unattainable.

\section{POSTSCRIPT}

A number of important developments specific to oil and gas exploration activity in the Mackenzie Delta-Beaufort Sea region have occurred since the Coastal Zone Conference 2006:

- The public hearing process of the Joint Review Panel for the Mackenzie Gas Project was extended from December 2006 to November 2007, primarily because stakeholder interest in addressing the Panel was much higher than initially anticipated. The extension of the public hearings will lengthen the timelines for the completion of the review process.

- Finalization of the Strategic Regional Plan was extended to early 2008 to provide greater opportunities for community involvement. Regulators are currently reviewing the draft recommendations and considering options for maintaining momentum on this initiative.

- On 12 March 2007, Imperial Oil Limited, on behalf of all proponents, revised the cost estimates of the Mackenzie Gas Project from $\$ 7$ billion to $\$ 16.2$ billion (Imperial Oil, 2007). The company also indicated that, should the project proceed, production start-up would be delayed from 2011 to 2014.

- On 7 October 2007, the National Energy Board declared a Significant Discovery for Devon Canada Corporation's Paktoa exploration program. Subsequent media announcements by the company indicated a recoverable resource potential of approximately 240 million barrels of oil.

- The number of active exploration licences in the Mackenzie Delta-Beaufort Sea region has continued to increase. Of particular note is the bid won by Imperial Oil Limited and Exxon Mobil for an exploration licence on a large offshore block in the Beaufort Sea based on a commitment to spend $\$ 585$ million on exploration activity (INAC, 2007a). The area in question is quite far offshore and in waters that are much deeper than traditional areas of exploration in the Beaufort Sea.

The Mackenzie Delta-Beaufort Sea region is becoming an increasingly dynamic area for oil and gas exploration activity. The regulatory, environmental, and infrastructure challenges identified at the Coastal Zone Conference 2006 nonetheless remain in play. Stakeholders must therefore continue to work closely with one another in order for the sustainable development of northern energy resources to become a reality. 


\section{ACKNOWLEDGEMENTS}

The authors wish to acknowledge the efforts of David Rosenberg, who edited the document, and of Keith Dewing and Benoît Beauchamp, who provided peer review. The final product is much improved as a result of their contributions. The views expressed in the article are those of the authors and may not reflect the positions of the authors' organizations.

\section{REFERENCES}

CLARK, K., HETHERINGTON, C., O’NEIL, C., and ZAVITZ, J. 1997. Breaking ice with finesse: Oil and gas exploration in the Canadian Arctic. Calgary, Alberta: The Arctic Institute of North America.

DION, S. 2004. Letter from the Honourable Stéphane Dion, Minister of the Environment, to Mr. Frank Pokiak, Chair, Inuvialuit Game Council, 29 November 2004. Available at http:// www.bsstrpa.ca/other_docs.htm.

DRUMMOND, K.J. 2002. Northern Canada distribution of ultimate oil and gas resources. Available from the Director General, Northern Oil and Gas Branch, Indian and Northern Affairs Canada, 10th Floor, 15 Eddy Street, Gatineau, Quebec $\mathrm{K} 1 \mathrm{~A} 0 \mathrm{H} 4$.
IMPERIAL OIL LIMITED. 2007. Mackenzie Gas Project proponents file revised cost and schedule information with National Energy Board and Joint Review Panel. News release, 12 March 2007. Available at www.imperialoil.ca/CanadaEnglish/News/News_Releases/N_NR_NewsRelease070312. asp.

IMPERIAL OIL LIMITED, ABORIGINAL PIPELINE GROUP, CONOCOPHILLIPS, SHELL CANADA, EXXONMOBIL. 2007. The Mackenzie Gas Project. Available at www.mackenzie gasproject.com.

INAC (INDIAN AND NORTHERN AFFAIRS CANADA). 2007a. Rights administration system. Available from Northern Oil and Gas Branch, Indian and Northern Affairs Canada, 10th Floor, 15 Eddy Street, Gatineau, Quebec K1A 0H4.

_. 2007b. Northern oil and gas annual report 2006. Available at http://www.ainc-inac.gc.ca/oil/ann/ann2006/mes_e.html.

POKIAK, F. 2004. Letter from Mr. Frank Pokiak, Chair, Inuvialuit Game Council, to the Honourable David Anderson, Minister of the Environment, 21 June 2004. Available at http:// www.bsstrpa.ca/other_docs.htm.

VOUTIER, K., MORRELL, G., and GREENALL, W. 2002. Federal preparedness for Beaufort Sea hydrocarbon exploration and development: The policy perspective. Available from the Director General, Northern Oil and Gas Branch, Indian and Northern Affairs Canada, 10th Floor, 15 Eddy Street, Gatineau, Quebec $\mathrm{K} 1 \mathrm{~A} 0 \mathrm{H} 4$ 